\title{
PENINGKATAN KINERJA, MITIGASI RISIKO DAN ANALISIS KELEMBAGAAN PADA RANTAI PASOK CABAI MERAH DI KABUPATEN GARUT
}

\section{PERFORMANCE IMPROVEMENT, RISK MITIGATION AND INSTITUSIONAL ANALYSIS OF RED CHILI SUPPLY CHAIN IN GARUT DISTRICT}

\author{
Maulida Hayuningtyas ${ }^{1 *}$, Marimin ${ }^{2)}$, dan Indah Yuliasih ${ }^{2)}$ \\ 1) Balai Besar Penelitian dan Pengembangan Pascapanen Pertanian \\ J1. Tentara Pelajar No 12 Komplek Pertanian Cimanggu Bogor 16114 \\ *Email : maulida.tia@gmail.com \\ 2) Pengajar diProgram Studi Teknologi Industri Pertanian, Fakultas Teknologi Pertanian, \\ Institut Pertanian Bogor -16602, Bogor - Indonesia \\ Makalah: Diterima 26 Maret 2019; Diperbaiki 22 Oktober 2019; Disetujui 20 November 2019
}

\begin{abstract}
Supply chain of red chilli has not integrated and involves all actor like farmers, collectors, traders, suppliers and industry. This condition creates instability in the quality of red chilli on the market, supply availability and price fluctuations. The purpose of this research was to study the mechanisms, performance, risk mitigation and institusional analysis of the supply chain using the Van de Vorst method, SCOR-AHP method, House of Risk (HOR) and Interpretative Structural Modeling (ISM). The location of this study was in Garut District, the highest production of red chili in West Java. The supply chain mechanism was approached through four elements, namely a) supply chain structure, b) chain business processes, c) network management and chain coordination, and d) chain resources used. The supply chain performance system has five levels of hierarchy, namely goals, business processes, criteria, attribute, and performance metrices. Results showed that the supply chain performances of the red chilli at farmers, collector, suppliers, and small medium enterprise (SME) were $74.6 \%, 76.8 \%, 82.5 \%, 81.9 \%$, respectively. Risk priorities showed there were 10 at the farmer, 9 at the traders, 11 at the supplier, and 10 at the industrial stage. Information on supply chain performance is expected to enable actors in the red chili supply chain to improve coordination, integration between actors, fulfillment of production facilities, proper implementation of Good Agricultural Practices (GAP), and distribution mechanisms, so that can optimally fullfil the consumer demand and minimize yield loss to improve competitiveness in the red chili industry.
\end{abstract}

Keywords : supply chain, performance, risk mitigation, institutional analysis

\section{ABSTRAK}

Cabai merah memiliki rantai pasok yang cukup panjang dan belum terintegrasi dengan melibatkan seluruh aktor petani, pengumpul, pedagang, supplier dan industri. Kondisi ini menimbulkan ketidakstabilan kualitas dan kuantitas cabai merah di pasaran, ketersediaan pasokan dan fluktuasi harga. Tujuan tulisan ini mengkaji mekanisme,kinerja, mitigasi risiko dan kelembagan rantai pasok cabai merah menggunakan metode SCOR-AHP (Supply Chain Operations Reference-Analitical Hierarchy Process), House of Risk (HOR) dan Interpretative Structural Modeling (ISM). Lokasi kajian di Kabupaten Garut sebagai wilayah dengan produksi cabai merah tertinggi di Jawa Barat. Mekanisme rantai pasok dianalisis dengan metode Vorst, melakukan pendekatan melalui empat elemen utama, yaitu a) struktur rantai pasok, b) proses bisnis rantai, c) manajemen jaringan dan koordinasi rantai,d), sumberdaya rantai yang digunakan. Sistem kinerja rantai pasok memiliki 5 hierarki level yaitu goal, proses bisnis, kriteria, atribut dan matriks kinerja. Hasil menunjukkan bahwa kinerja pada mata rantai cabai merah antara lain petani sebesar 74,6\%, pengumpul 76,8\%, supplier $82,5 \%$ dan industri kecil menengah (IKM) sebesar $81, \%$. Prioritas risiko menunjukkan ada 10 risiko potensial pada petani, 9 risiko potensial pada pedagang, 11 risiko potensial pada pemasok dan 10 risiko potensial pada tahap industri. Informasi kinerja rantai pasok ini diharapkan para pelaku di rantai pasok cabai merah meningkatkankoordinasi, integrasi antara pelaku rantai pasok, pemenuhan sarana produksi, penerapan GAP (Good Agricultural Practices) yang tepat, mekanisme distribusi pasokan, sehingga dapat optimal untuk memenuhi permintaan konsumen dan memperkecil kehilangan hasil untuk meningkatan daya saing pada industri cabai merah.

Kata kunci: rantai pasok, kinerja, mitigasi risiko, analisis kelembagaan

\section{PENDAHULUAN}

Cabai merah (Capsicum annum L.) merupakan salah satu produk hortikultura yang dibudidayakan di Indonesia, dan komoditas yang tidak dapat disubstitusi karena memiliki rasa yang khas. Produksi cabai merah di Indonesia semakin meningkat seiring dengan jumlah konsumsi, hingga tahun 2017 produksi cabai merah mencapai 1.206.266 ton (BPS, 2017). Provinsi Jawa Barat menjadi salah 
satu sentra produksi yang mensuplai sebesar $\pm 22,9 \%$ cabai merah untuk memenuhi kebutuhan masyarakat terutama di kota besar. Kabupaten Garut ialah daerah yang memiliki wilayah dataran tinggi dan agroklimat basah sesuai untuk membudidayakan komoditas hortikultura (Dinas Pertanian, 2010). Konsumsi cabai merah sebagian besar masih dalam bentuk segar dan kebutuhannya semakin meningkat, salah satunya ialah perkembangan ilmu kulinologi dan industri di sektor hilir sehingga konsumen menuntut kualitas produk yang baik.

Karakteristik produk pertanian ialah tidak tersedianya informasi yang tepat waktu, relevan dan dapat diandalkan tentang peluang pasar saat ini termasuk jenis, kuantitas dan kualitas produk yang dibutuhkan, peraturan pasar, dan permintaan dan harga musiman (Marimin et al., 2010). Kualitas yang dituntut oleh konsumen menjadi salah satu elemen kunci, karena cabai merah menjadi sumber vitamin A, vitamin $\mathrm{C}$, senyawa flavonoid dan karotenoid yang dipengaruhi oleh kultivar, kematangan, kondisi pertumbuhan dan penanganan pascapanen (Zhuang et al., 2012). Selain itu, komponen utama dari kualitas produk hortikultura ialah dari penampilan, tekstur, flavour yang dapat dirasa dengan panca indera (Ahmad, 2013). Ketergantungan konsumen pada cabai merah segar diupayakan dengan mengalihkan ke beberapa produk olahan untuk mengatur pola pasokan, kualitas dan kuantitas pasokan. Berdasarkan pola distribusi perdagangan cabai merah di Jawa Barat konsumen akhir yaitu rumah tangga, industri pengolahan dan kegiatan usaha lainnya, konsumen rumah tangga merupakan konsumen tertinggi dengan presentase distribusi hingga 76.58\% (BPS, 2015).

Manajemen rantai pasok merupakan integrasi dari proses bisnis dalam rantai pasok untuk mencapai tujuan dengan menciptakan nilai bagi kepuasan konsumen dan aktor lainnya (Lambert, 2008). Mekanisme rantai pasok berbeda pada setiap komoditas dan daerah. Pengembangan manajemen rantai pasok pada komoditas cabai merah adalah budaya wirausaha masih lemah, mutu bervariasi, ketersediaan teknologi unggul masih terbatas, produktivitas rendah, penanganan pascapanen kurang memadai, harga berfluktuasi serta belum efisiennya sistem distribusi komoditas cabai merah (Saptana, 2013). Rantai pasok di komoditas hortikultura bervariasi sesuai kebutuhan dan kemitraan yang terjalin setiap aktor. Jalur distribusinya dengan banyaknya aktor yang terlibat, dapat menjadi kendala dalam pengendalian kualitas, sehingga perlu ada penyesuaian rancangan dalam memaksimalkan kinerja rantai pasok.

Pengukuran kinerja bertujuan untuk mendukung perancangan tujuan, evaluasi kinerja, dan menentukan langkah-langkah ke depan baik pada level strategi, taktik dan operasional (Van der Vorst, 2006). Kinerja rantai pasok menjadi sebuah strategi untuk berdaya saing menyeimbangkan antara rasa kepuasan konsumen dan efisiensi produsen (Chopra dan Meindhl, 2013). Kinerja rantai pasok menjadi bagian yang krusial dalam pelaksanaannya, karena berhasilnya suatu rantai pasok harus didukung oleh semua pihak yang terlibat.

Peningkatan kinerja dapat menimbulkan risiko pada rantai pasok, salah satunya ialah dengan adanya perubahan kualitas produk. Risiko tidak hanya pada aktor sendiri tetapi risiko kepada semua aktor dalam rantai pasok (Hallikas dan Varis, 2009). Hal tersebut berakibat pada interaksi antar aktor dan risiko yang dihadapi sehingga menyebabkan kerugian secara menyeluruh dalam jaringan pasokan (Marimin dan Maghfiroh, 2011). Penilaian kinerja dapat ditingkatkan sehingga menurunkan risiko yang dihadapi oleh aktor. Analisis kelembagaan dalam rantai pasok diperlukan untuk mempertahankan suplai pasokan. Selain itu, perlunya struktur kelembagaan yang efektif dan efisien memenuhi kebutuhan aktor yang terlibat dalam pencapaian tujuan.

Fluktuasi harga cabai merah sangat cepat karena terjadi ketidakseimbangan jumlah pasokan di pasaran. Kontinuitas pasokan berada dalam rantai pasok yang panjang, sentra produksi yang terpusat pada daerah tertentu hingga nilai impor yang semakin menanjak. Kondisi ini sangat berpengaruh terhadap kinerja rantai pasok cabai merah untuk memenuhi kebutuhan pasokan dengan kualitas yang baik secara kontinu.

Prospek dan peluang pengembangan manajemen rantai pasok cabai merah besar direfleksikan oleh potensi lahan yang cukup tersedia, kesenjangan produktivitas antar lokasi masih tinggi, bernilai ekonomi tinggi, permintaan pasar terus meningkat, dukungan kelembagaan profesi cukup baik, permintaan untuk pasokan bahan baku untuk industri pengolahan cukup tinggi, serta adanya dukungan program pemerintah (Saptana, 2013).

Tujuan penelitian ini adalah mengidentifikasi mekanisme rantai pasok, menganalisis pengukuran kinerja, identifikasi dan mitigasi risiko serta menganalisis kelembagaan pada rantai pasok cabai merah. Hasil penelitian ini diharapkan dapat menjadi masukan bagi pengambil kebijakan dan pelaku rantai pasok meliputi petani, pengumpul dan supplier dalam meningkatkan kinerjanya. Lokasi kajian di Kabupaten Garut sebagai wilayah dengan produksi cabai merah tertinggi di Jawa Barat.

\section{METODE PENELITIAN}

\section{Kerangka Konseptual}

Penelitian ini dilakukan untuk melihat mekanisme rantai pasok dengan mengidentifikasi proses bisnis pada komoditas cabai merah, menganalisis pengukuran kinerja, menganalisis mitigasi risiko dan analisis kelembagaan rantai pasok di setiap aktor mata rantai. Perancangan metode pengukuran kinerja dibangun dengan 
mengidentifikasi metrik kinerja dan penentuan bobot metrik pengukuran kinerja, selanjutnya dilakukan implementasi dan integrasi penilaian metode pengukuran kinerja rantai pasok. Mitigasi risiko diawali dengan identifikasi risiko yang terjadi dalam rantai pasok berdasarkan nilai kinerja, dan dilakukan mitigasi pada risiko tersebut. Analisis kelembagaan dilakukan untuk mengevaluasi kelembagaan eksisting pada rantai pasok cabai merah (Gambar 1).

\section{Teknik Pengumpulan Data}

Penelitian ini menggunakan data primer dan data sekunder yang diperoleh antara lain studi pustaka dan observasi lapang terkait dengan manajemen rantai pasok, analisis kinerja dan risiko serta analisis kelembagaan rantai pasok untuk melihat langsung kondisi eksisting dan kegiatan yang berkaitan dengan aktivitas rantai pasok. Kuesioner semi terstruktur untuk memperoleh informasi mengenai matriks kinerja, jenis-jenis risiko dan mitigasi serta keterkaitan elemen dalam model kelembagaan. Wawancara dengan stakeholder terkait seperti Dinas
Pertanian Kabupaten Garut, kelompok tani, koperasi, IKM cabai merah bubuk, pasar induk untuk memperoleh informasi dan mengklarifikasi permasalahan yang terjadi di lapangan. Opini pakar untuk memperoleh informasi terkait variabel yang mempengaruhi kinerja, risiko dan kelembagaan cabai merah saat ini.

\section{Metode Analisis Data}

Metode analisis data yang digunakan pada penelitian ini antara lain : 1) kondisi umum dan model rantai pasok dianalisis dengan mengunakan metode deskriptif-kualitatif yang dikembangkan oleh Asian Productivity Organization (APO) (Arshinder dan Desmukh, 2008), dengan memperhatikan pendapat pakar dan nara sumber; 2) AHP (Analytical Hierarchy Process) untuk penentuan bobot matrik pengukuran kinerja yang dilakukan melalui tahapan perbandingan parameter dalam SCOR; 3) pengukuran kinerja rantai pasok cabai merah dilakukan dengan menggunakan metode SCOR.

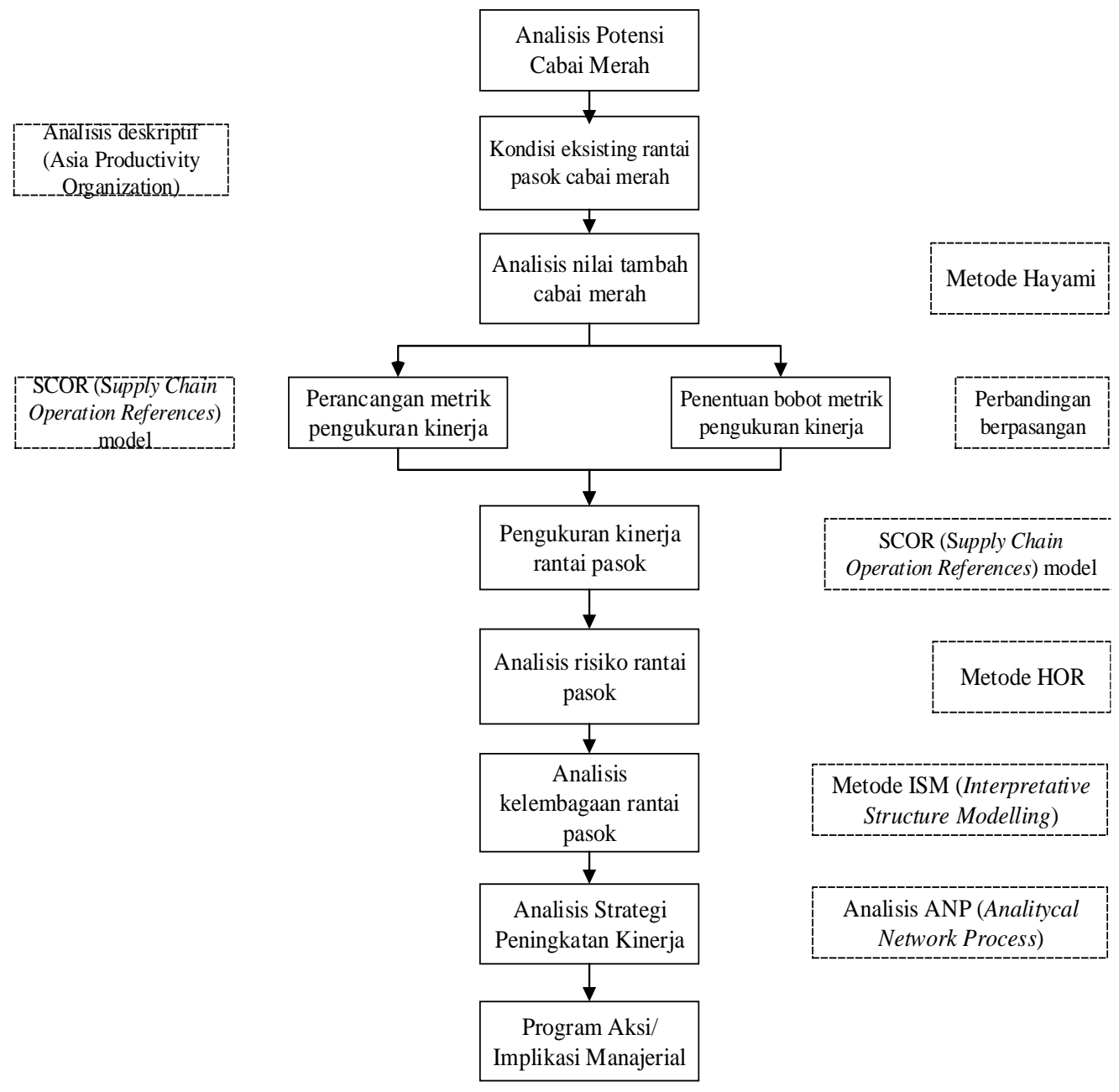

Gambar 1. Kerangka pemikiran penelitian 
Pembobotan AHP menggunakan software Expert Choice 11 dan selanjutnya hasil dari parameter tersebut akan dikalikan dengan pembobotan matriks dari kuisioner pakar; 4) Mengidentifikasi kejadian dan sumber risiko berdasarkan elemen SCOR, melakukan perhitungan dan aksi mitigasi dari risiko prioritas; 5) mengidentifikasi elemen-elemen kelembangan hingga mendapatkan elemen kunci untuk menjadi dasar dari penyusunan struktur kelembagaan.

Mekanisme rantai pasok akandianalisis dengan menggunakan metode berdasarkan Van de Vorst, yaitu melakukan pendekatan melalui empat elemen utama (Gambar 2): a) struktur rantai, b) proses bisnis rantai, c) manajemen jaringan, d) sumberdaya rantai.

AHP merupakan suatu proses yang bertujuan untuk membantu para pengambil keputusan mendapatkan pilihan terbaik dengan memberikan nilai bobot dari kriteria, subkriteria, alternatif dengan perbandingan berpasangan (pairwise comparision). Prinsip kerja AHP ialah menyederhanakan permasalahan kompleks ke dalam bentuk yang lebih sederhana kemudian melakukan sintesis terhadap berbagai faktor (Marimin, 2004). Ada empat buah prinsip dasar AHP yang harus dipahami, yaitu: 1) penyusunan hirarki, 2) penilaian kriteria dan alternatif, 3) penentuan prioritas, 4) konsistensi logis (Saaty, 2006).

Penelitian menggunakan model SCOR membantu mengidentifikasi kesenjangan dan ketidakefisienan dalam proses. Praktik terbaik memperbaiki inefisiensi rantai pasok dengan praktik dan saran pendukung yang terbaik dari berbagai praktik yang berbeda. Struktur dasar dari model referensi memeriksa lima proses rantai pasok yaitu plan, source, make, deliver, return dan enable (Georgise et al., 2013). Plan merupakan perencanaan produksi atau budidaya, source mencari dan memilih sumber dalam perencanaan tersebut, make ialah melakukan proses produksi atau budidaya di bagian produsen dan pasca budidaya, deliver merupakan kegiatan yang berkaitan dengan model pengiriman hasil produksi, return ialah pengembalian yang dilakukan pelaku jika terjadi ketidaksesuaian hasil kesepakatan dan enable ialah pengelolaan manajemen rantai pasok yang konsisten. Model SCOR merupakan sistem untuk mengukur kinerja pada setiap level dalam proses bisnis rantai pasok meliputi perencanaan, pengadaan, pengolahan, pengiriman dan pengembalian (Jamehshooran, 2015).

Analisis risiko diawali identifikasi kejadian dan sumber risiko, penilaian risiko dan penentuan nilai Aggregate Risk Potential (ARP), serta mitigasi risiko pada rantai pasok. Identifikasi risiko mengacu pada kerangka rantai pasok SCOR. Penurunan kejadian sumber risiko akan mencegah sebagian dari kejadian risiko yang terjadi (Ulfah, 2016). Penilaian risiko untuk menilai tingkat keparahan (S), tingkat kemunculan risiko $(\mathrm{O})$ dan korelasi $(\mathrm{R})$ kejadian dan sumber risiko. Sub-model penentuan nilai (ARP) mengacu pada kerangka House of Risk(HOR) 1 (Pujawan dan Geraldin, 2009) sesuai Persamaan 1. Identifikasi aksi-aksi untuk mencegah munculnya risiko (Preventive Actions (PAk)), menentukan korelasi antara aksi pencegahan dan agen risiko (Ejk) dan menjadi efektivitas total (TEk) sesuai persamaan 2. Penilaian tingkat kesulitan (Difficulty (Dk)) dalam masing masing aksi mitigasi dan nilai total efektivitas (ETD) sesuai persamaan 3. Matrik perhitungan model mengacu pada HOR2.

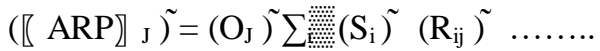

$$
\begin{aligned}
& \mathrm{TE}_{\mathrm{k}}=\Sigma A R P_{j} \cdot E_{j k} \forall j j \\
& E T D=T E_{k} / D_{k}
\end{aligned}
$$

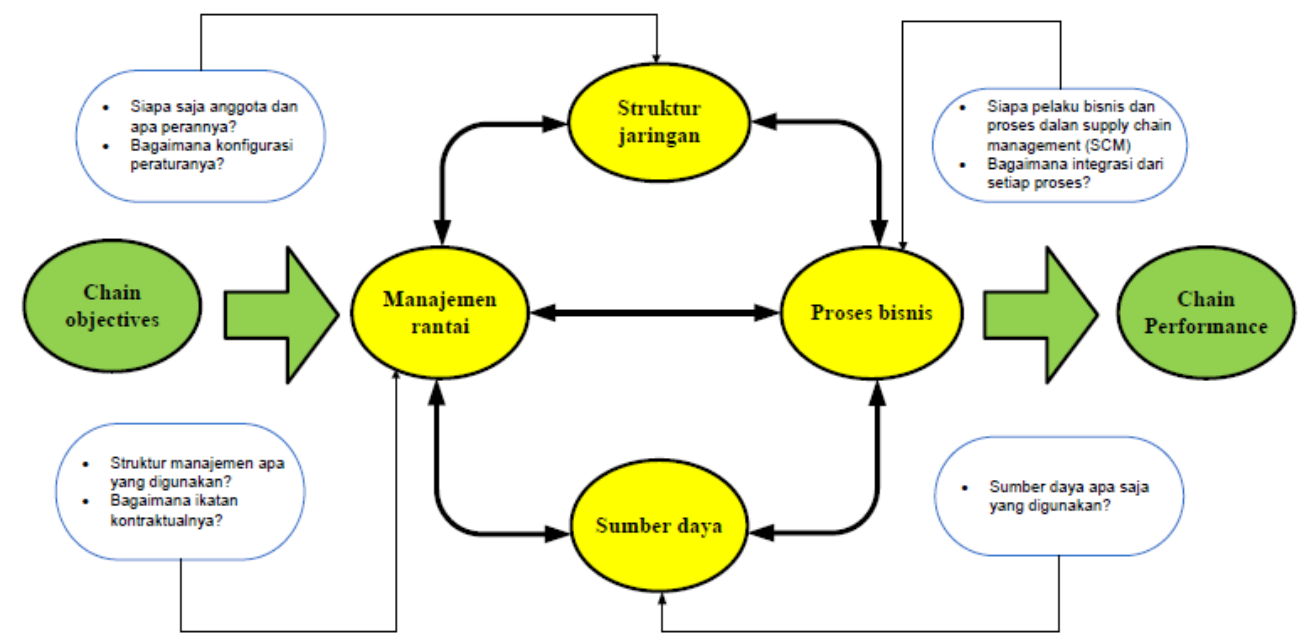

Gambar 2. Kerangka analisis rantai pasok (Van de Vorst, 2006) 
Keterangan:

$$
\begin{aligned}
& \mathrm{ARP}_{\mathrm{j}}=\text { Potensi risiko aktor } \\
& \mathrm{O}_{\mathrm{j}} \quad=\text { Tingkat kemunculan risiko- } \mathrm{j} \\
& \mathrm{S}_{\mathrm{i}} \quad=\text { Tingkat keparahan risiko ke-i } \\
& \mathrm{R}_{\mathrm{ij}}=\text { Korelasi tingkat kemunculan risiko } \\
& \text { ke-j dan dan tingkat keparahan } \\
& \text { risiko ke-i } \\
& \mathrm{TE}_{\mathrm{k}}=\text { Total efektivitas aksi mitgasi risiko } \\
& \text { ke-k } \\
& \mathrm{E}_{\mathrm{jk}}=\text { Korelasi antara tingkat kemunculan } \\
& \text { risiko ke j dengan aksi mitigasi ke- } \\
& \mathrm{k} \\
& \text { ETD = Nilai total efektivitas dari aksi } \\
& \text { mitigasi } \\
& \mathrm{D}_{\mathrm{k}}=\text { Tingkat kesulitan dari aksi mitigasi } \\
& \text { ke-k }
\end{aligned}
$$

Model kelembagaan rantai pasok cabai merah menjadi salah satu bagian untuk meningkatkan kinerja, karena berkaitan dengan pengelolaan suplai pasokan. ISM adalah proses penilaian kelompok yang menghasilkan model struktural untuk menggambarkan subjek yang kompleks dari suatu sistem, melalui pola yang dirancang menggunakan grafik dan kalimat (Eriyatno, 2013). Teknik ISM dibagi menjadi dua bagian, yaitu klasifikasi elemen dan penyusunan hirarki. Langkah pertama adalah menentukan elemen-elemen yang sesuai dengan permasalahan yang ada, selanjutnya disusun subelemen pada setiap elemen yang terpilih. Pemilihan elemen dan penyusunan sub elemen dilakukan dari hasil diskusi dengan pakar.

Hasil penilaian tersebut tersusun dalam Structural Self Interaction Matrix (SSIM) yang dibuat dalam bentuk tabel Rechability Matrix (RM) dengan mengganti $\mathrm{V}, \mathrm{A}, \mathrm{X}, \mathrm{O}$ menjadi bilangan 1 dan 0 . Klasifikasi elemen didasarkan pada SSIM yang dibuat berdasarkan sistem VAXO, yaitu: $\mathrm{V}$ jika eij $=$ 1 dan eji $=0$; A jika eij $=0$ dan eji $=1 ; X$ jika eij $=1$ dan eji $=1 ; O$ jika eij $=0$ dan eji $=0$. Matrik yang telah memenuhi transivity dilanjutkan pengolahannya untuk mendapatkan RM, untuk mendapatkan Driver Power (DP) dan Dependence (D). Tahap terakhir adalah mengelompokkan sub-sub elemen kedalam 4 sektor yaitu autonomous, dependent, linkage dan independent.

\section{HASIL DAN PEMBAHASAN}

\begin{tabular}{|c|c|}
\hline$----\cdot \cdot$ & Jalur 1, melalui pengepul dan supplier untuk industri \\
\hline----+---1 & Jalur 2, melalui pemasok, pedagang besar, pedagang eceran hingga konsumen akhir \\
\hline$\cdot-\cdots$ & Jalur 3, melalui dapoktan, koperasi dan industri \\
\hline $\begin{array}{l}---1 \\
1 \\
-1-1\end{array}$ & $\begin{array}{l}\text { Jalur 4, melalui pengepul kecil/gapoktan hingga pengepul besar } \\
\text { Jalur 5, melalui pengepul kecil, trading online hingga konsumen akhir }\end{array}$ \\
\hline
\end{tabular}

\section{Kondisi Rantai Pasok Cabai Merah}

Struktur jaringan rantai pasok cabai merah bervariasi terdiri dari petani, pengepul, pedagang, supplier, koperasi, retail, UKM dan industri. Rantai pasokcabai merah Kabupaten Garut terdapat beberapa jalur distribusi hingga konsumen akhir,yaitu rumah tangga maupun industri pengolahan dan usaha lainnya (Gambar 3). Jalur distribusi telah lama terbentuk, cabai merah didistribusikan ke konsumen sebagian besar dalam kondisi segar, s edangkan kebutuhan industri untuk produk pasta dan cabai kering sebesar $28 \%$ dari seluruh total produksi.

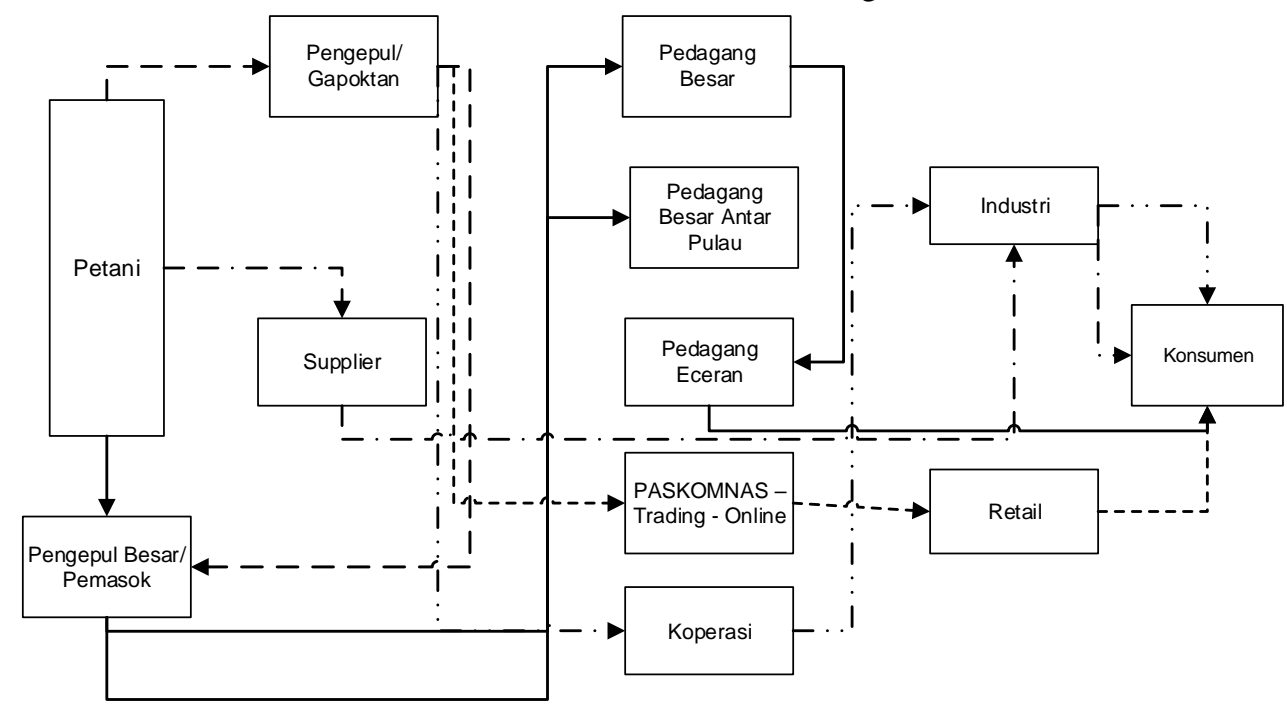

Keterangan :

Gambar 3. Struktur jaringan rantai pasok cabai merah 
Terdapat beberapa titik kritis dalam penanganan cabai merah sehingga manajemen rantai pasok dan penerapan Good Handling Pratices (GHP) dari proses panen hingga distribusi harus dalam pengawasan. Saat ini, dalam manajemen rantai pasok bahwa kerjasama dan pemilihan mitra berdasarkan pada kepercayaan serta belum adanya kesepakatan kontrak dalam sistem transaksi.

Proses bisnis rantai pasok terdiri dari aliran barang dari petani/ kelompok tani yang dikirim ke pengumpul untuk disortir dan dikemas, kemudian produk dikirim ke supplier kemudian langsung kepada IKM yang mengolah produk akhir sebelum ke konsumen. Sebaliknya aliran finansial mengalir dari konsumen, retail kembali ke supplier, pengepul, kemudian dari pengepul ke petani/kelompok tani, sedangkan aliran informasi berlaku dua arah, dapat dimulai dari permintaan konsumen kepada produsen, maupun dari arah produsen untuk pemenuhan kebutuhan konsumen.

Mekanisme pembayaran atau aliran uang yang terjadi dalam rantai cabai merah terdapat tiga jenis, yaitu (1) petani dengan pengumpul, pembayaran secara tunai sesuai dengan jumlah yang diterima oleh pengumpul dan antara pengumpul dengan supplier,(2) cabai merah dengan tujuan langsung ke pasar, aliran uang dari pengumpul dengan pedagang akan dibayarkan setelah barang yang di pasar terjual, (3) IKM akan melakukan pembayaran secara putus dengan pihak distributor, jumlah produk terjual akan menjadi tanggungjawab distributor.

Sasaran rantai pasok cabai merah ialah dengan mengetahui kualitas produkhinggadi pasaran dan menentukan harga jual produk. Perluasan jaringan dengan memanfaatkan trading online dapat menjangkau lebih banyak dan beragam konsumen retail, hotel dan restoran. Pengembangan pola kemitraan terutama industri olahan cabai merah dapat diperluas melalui koperasi milik kelompok petani. Kemitraan terkadang tidak berjalan baik karena kesepakatan kedua belah pihak tidak berjalan dengan baik, dari segi harga dan persyaratan kualitas produk.

Manajemen rantai pasok di pedagang besar atau pasar induk hanya terekap untuk jumlah dan asal daerah pasokan, tidak ada identitas personal. sedangkan untuk manajemen supplier memenuhi kuota kebutuhan produksi, karena kegiatan pengolahan primer berupa pengeringan dan penggilingan menjadi bubuk cabai berkoordinasi dengan pemasok tertentu. Hal tersebut juga dilakukan pada bahan pendukung produksi selain cabai merah. Kriteria produk cabai bubuk telah ditentukan oleh IKM, sehingga supplier mengupayakan sesuai untuk menjaga kepercayaan dan hubungan rantai pasok tersebut.

Sumberdaya rantai pasok cabai merah di sentra produksi Kabupaten Garut memiliki luas panen 5.816 ton per tahun. Jumlah tersebut untuk memenuhi kebutuhan daerah sendiri maupun ke luar kota. Produk bubuk cabai yang dikembangkan oleh IKM memiliki daya saing dan permintaan yang tinggi, karena penggunaannya yang praktis. Hasil dari petani ke pengumpul kemudian dilakukan sortasi sebelum ke supplier untuk diolah dan dijadikan produk setengah jadi. Industri melakukan proses pencampuran dan pengemasan sebelum di jual ke pasar.

\section{Metrik Pengukuran Kinerja}

Struktur hirarki pemilihan metrik pengukuran kinerja rantai pasok cabai merah terdiri dari level 1 proses bisnis mengacu pada enam kegiatan meliputi perencanaan, pengadaan, budidaya, pengolahan, pengiriman dan pengelolaan. Level 2 parameter kinerja, level 3 atribut kinerja dan level 4 metrik kinerja. Parameter kinerja meliputi nilai tambah, produktivitas, kualitas, dan risiko. Atribut kinerja meliputi reliabilitas, fleksibilitas, biaya, responsivitas. Rancangan metrik kinerja meliputi kinerja pengiriman, pemenuhan pesanan, kesesuaian dengan standar mutu, siklus waktu pemenuhan pesanan, siklus waktu pengolahan, fleksibilitas jumlah pasokan, biaya rantai pasok, biaya pengolahan. Bobot numerik dalam setiap elemen hirarki dapat mengoptimalisasi kinerja rantai pasok, yang nilainya didapatkan dari penilaian pakar dan mewakili dari lingkup akademisi, pemerintah dan praktisi.

Pembobotan pada matriks kinerja yang dibutuhkan dalam perhitungan kinerja menggunakan hasil identifikasi awal rantai pasok cabai merah, dari siklus pemenuhan pesanan, jadwal pengiriman, pemenuhan permintaan. Bobot tertinggi dalam level 1 ialah proses perencanaan, karena menjadi titik kritis dalam kinerja petani untuk meningkatkan produktivitas. Pada level 2 bobot kriteria kinerja untuk kualitas, bahwa dengan perencanaan yang benar akan menghasilkan produk yang berkualitas. Level 3 yaitu atribut kinerja ialah dengan mengutamakan reliabilitas, bagaimana kemampuan setiap aktor rantai pasok untuk memenuhi permintaan konsumen secara kontinu. Hasil analisis AHP dengan mengadaptasi model evaluasi SCOR menghasilkan metrik pengukuran kinerja di level 4 dengan bobot tiga tertinggi ialah leadtime pemenuhan pesanan $(0,151)$, fleksibilitas rantai pasok $(0,130)$ dan kondisi sempurna (0,124). Metrik kinerja tersebut memperlihatkan bahwa dalam rantai pasok pemenuhan kebutuhan konsumen sangat penting terutama dalam stabilitas harga dan jumlah pasokan. Sedangkan fleksibilitas rantai pasokan pada mata rantai supplier diperlukan untuk menjadi penyangga jika kebutuhan konsumen mengalami lonjakan tinggi dan turun serta kondisi sempurna menjadi faktor daya saing produk (Gambar 4). 


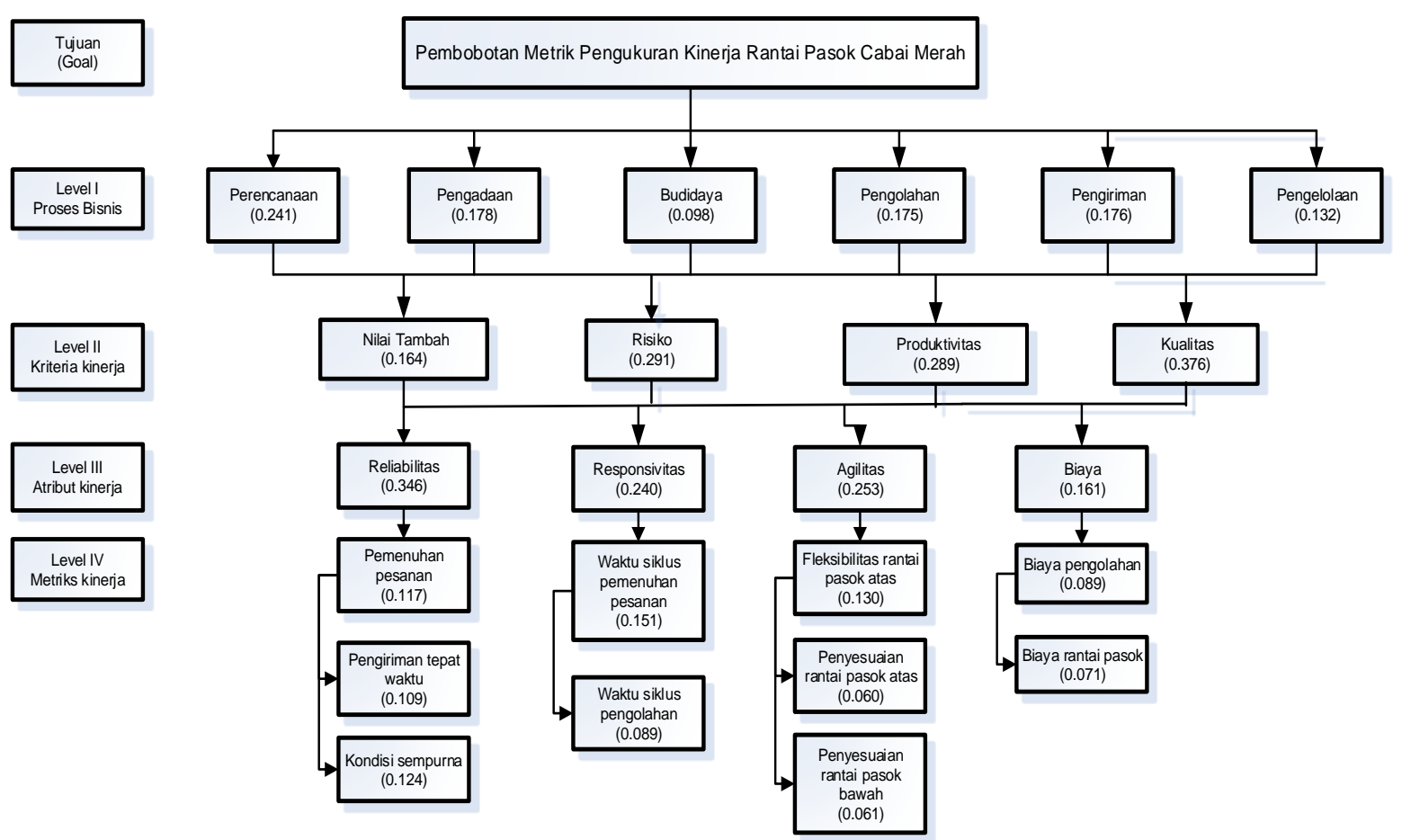

Gambar 4. Bagan kinerja SCOR-AHP rantai pasok cabai merah

Hasil nilai aktual dan metrik kinerja menunjukkan bahwa kinerja pada pelaku rantai pasok cabai merah yaitu petani sebesar $74,6 \%$, pengumpul $76,8 \%$, supplier $82,5 \%$ dan IKM sebesar $81,9 \%$. Dari hasil tersebut untuk rantai pasok melalui 4 aktor rantai dari petani, pengumpul dengan nilai kinerja $<80 \%$ sedangkan supplier dan industri dengan nilai kinerja $>80 \%$. Menurut Moenzcka 2009, untuk klasifikasi nilai standar kinerja berada dalam kriteria sedang dan kurang. Hasil penilaian kinerja rantai pasok cabai merah dengan melibatkan petani, pengumpul, supplier dan industri terdapat pada Tabel 1 .

Setiap aktor dapat meningkatkan kinerja dalam kategori baik, sehingga rantai pasok dapat terintegrasi dalam memaksimalkan pola distribusinya. Untuk mencapai kinerja tertinggi dapat dioptimalkan dengan memperbaiki beberapa kriteria untuk mencapai bobot pada metrik kinerja. Terdapat beberapa faktor dari kurangnya kinerja petani dan pengumpul, karena minimnya ketersediaan sumber air, selama musim selama 5 bulan kebutuhan air harus terpenuhi agar produksi maksimal dan tidak kekeringan, sedangkan pada musim hujan, mengoptimumkan penggunaan pestisida untuk mencegah hama penyakit. Selain itu, benih varietas unggul dengan produktivitas tinggi dan penanganan pascapanen dilakukan untuk mempertahankan kualitas produk hingga di pasaran.

Kinerja pengumpul dapat ditingkatkan dengan hasil produksi cabai merah berkualitas baik sehingga tidak terdapat cabai yang hilang (loss) dan tidak lolos kriteria. Proses sortasi, penimbangan, pengemasan harus dilakukan sebaik mungkin dengan adanya pencatatan jumlah pasokan yang dikirim.
Peningkatan kinerja supplier dapat dilakukan pada pengolahan produk cabai bubuk dengan rendemen tinggi. Kinerja industri ditingkatkan dengan pola pemasaran distributor dan trading online untuk pasar horeka (hotel, restoran dan katering). Pengembangan pola pemasaran diharapkan mampu meningkatkan jumlah pesanan dan produksi setiap harinya, dikarenakan IKM perlu melakukan pengembangan dengan menjalin kemitraan.

Adanya kinerja rantai pasok ini diharapkan memberikan informasi kepada aktor rantai akan pentingnya sinergi dan integrasi antar aktor. Kerjasama dalam kegiatan rantai pasok dalam memenuhi permintaan konsumen harus secara optimal. Hal tersebut bertujuan untuk meningkatkan kualitas produk cabai merah dalam berdaya saing serta menurunkan angka kehilangan hasil. Kinerja rantai pasok secara umum akan mempengaruhi startegi persaingan suatu proses bisnis dalam rantai pasok.

\section{Identifikasi dan Mitigasi Risiko Rantai Pasok Cabai Merah}

Kinerja rantai pasok juga sejalan dengan adanya risiko yang terjadi di setiap aktor rantai. Tingkat performa yang kurang maksimum karena terdapat beberapa permasalahan yang menjadi risiko untuk dihadapi rantai pasok. Identifikasi risiko dilakukan pada proses bisnis rantai pasok berdasarkan dimensi SCOR, yaitu perencanaan, pengadaan, pengolahan, pengiriman, dan pengelolaan yang di uraikan menjadi masing masing sub proses secara detail dan potensial terjadi di dalam rantai pasok (Septiani et al., 2017). 
Tabel 1. Kinerja aktor pada rantai pasok cabai merah

\begin{tabular}{llrrrrr}
\hline \multirow{2}{*}{$\begin{array}{c}\text { Atribut } \\
\text { kinerja }\end{array}$} & \multicolumn{1}{c}{ Matriks kinerja } & \multicolumn{3}{c}{ \% Nilai Matriks Kinerja } \\
\cline { 3 - 6 } Reliabilitas & Pemenuhan pesanan & 0,117 & 9,185 & 8,768 & 11,690 & 10,521 \\
& Pengiriman tepat waktu & 0,109 & 8,402 & 8,164 & 10,885 & 10,885 \\
& Kondisi sempurna & 0,124 & 9,591 & 7,999 & 10,963 & 12,425 \\
\multirow{2}{*}{ Responsivitas } & Waktu siklus pemenuhan pesanan & 0,151 & 15,096 & 7,548 & 7,548 & 15,096 \\
& Waktu siklus pengolahan & 0,089 & 8,904 & 5,936 & 8,904 & 8,904 \\
Agilitas & Fleksibilitas rantai pasok atas & 0,130 & 12,975 & 6,488 & 8,650 & 12,975 \\
& Penyesuaian rantai pasok atas & 0,060 & 0,000 & 0,000 & 5,950 & 2,380 \\
& Penyesuaian rantai pasok bawah & 0,061 & 0,000 & 0,000 & 3,038 & 0,000 \\
Biaya & Biaya pengolahan & 0,089 & 4,432 & 14,773 & 8,864 & 6,666 \\
& Biaya rantai pasok & 0,071 & 6,098 & 17,126 & 6,047 & 2,049 \\
\hline & Total & & $\mathbf{7 4 , 6 8 2}$ & $\mathbf{7 6 , 8 0 1}$ & $\mathbf{8 2 , 5 3 9}$ & $\mathbf{8 1 , 9}$ \\
\hline
\end{tabular}

Identifikasi risiko berdasarkan nilai kinerja rantai pasok dan berdasarkan House of Risk (HOR) 1, ialah risiko dianalisis berdasarkan tingkat keparahan pada kejadian risiko ( $\mathrm{Si}$ ) untuk petani, pengumpul, supplier dan industri. Selanjutnya, tingkat frekuensi kemungkinan terjadinya sumber risiko yang muncul pada rantai pasok (Oi) diuraikan dalam beberapa elemen di Tabel 2 dan 3.

Tabel 2. Tingkat keparahan terjadinya kejadian risiko di tingkat pengumpul

\begin{tabular}{|c|c|c|}
\hline Kejadian Risiko & Kode & $\mathbf{S i}$ \\
\hline $\begin{array}{l}\text { Perencanaan kuantitas pengriman } \\
\text { tidak sesuai }\end{array}$ & E1 & 6,5 \\
\hline $\begin{array}{l}\text { Jadwal pengiriman terlambat } \\
\text { Hasil produksi tidak memenuhi }\end{array}$ & E2 & 7,5 \\
\hline kuota & E3 & 8,5 \\
\hline Perubahan kualitas produk & E4 & 8 \\
\hline $\begin{array}{l}\text { Produk tidak sesuai dengan pasar } \\
\text { Kekurangan kapasitas pengiriman }\end{array}$ & E5 & 7 \\
\hline $\begin{array}{l}\text { produk } \\
\text { Ketidaksesuaian penggunaan }\end{array}$ & E6 & 8,5 \\
\hline kemasan & E7 & 6,5 \\
\hline $\begin{array}{l}\text { Permintaan pasar tidak mampu } \\
\text { dipenuhi }\end{array}$ & E8 & 7,5 \\
\hline Harga jual produk rendah & E9 & 6,5 \\
\hline $\begin{array}{l}\text { Adanya bahan baku yang loss atau } \\
\text { rusak dalam pengiriman }\end{array}$ & E10 & 8,5 \\
\hline $\begin{array}{l}\text { Ketidaksesuaian jumlah produksi } \\
\text { di kebun dan pengumpul }\end{array}$ & E11 & 6,5 \\
\hline $\begin{array}{l}\text { Tidak ada perhitungan total } \\
\text { pengiriman }\end{array}$ & E12 & 8,5 \\
\hline $\begin{array}{l}\text { Tidak tersediaanya sarana } \\
\text { pendukung }\end{array}$ & E13 & 7 \\
\hline
\end{tabular}

Hasil identifikasi kejadian risiko rantai pasok menunjukkan terdapat 19 kejadian risiko pada petani, 13 pada pengumpul, 20 pada supplier, dan 20 pada industri. Sumber risiko adalah faktor-faktor yang dapat menyebabkan terjadinya suatu kejadian risiko atau berlaku sebaliknya.
Tabel 3. Tingkat keparahan terjadinya kejadian risiko di tingkat supplier

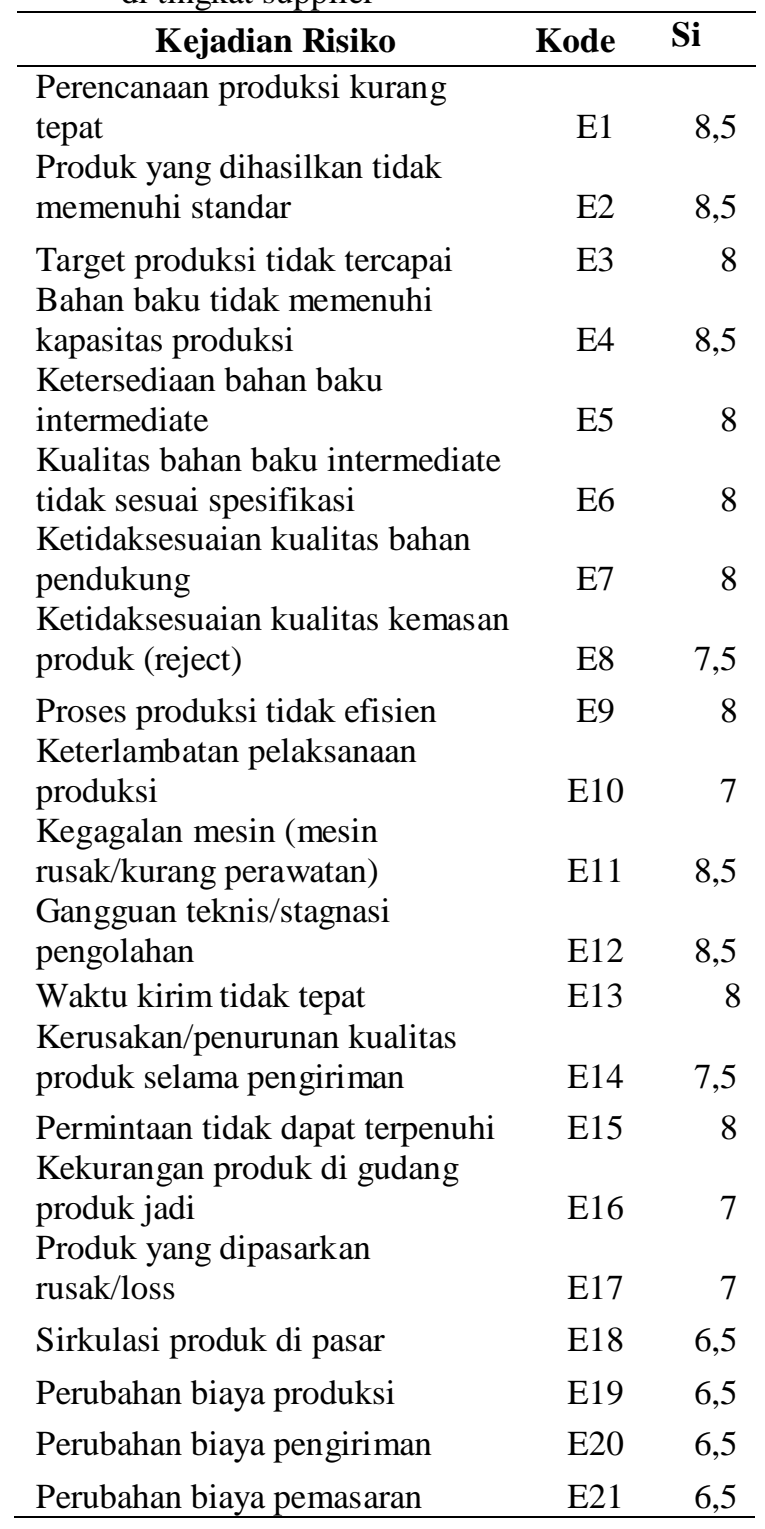


Identifikasi sumber risiko yang mungkin terjadi di tingkat pengumpul sebanyak 13 jenis dan dapat terjadi selama kegiatan rantai pasok berjalan. Sumber risiko juga dapat teridentifikasi terjadinya interaksi antar pengumpul tersebut, dan pihak-pihak yang berhubungan dengan pelaku rantai pasok. Pemahaman tentang risiko dalam rantai pasok akan membantu dalam membuat keputusan yang lebih baik dan mengurangi risiko dalam keseluruhan jaringan rantai pasok (Hallikas et al., 2004).

Pemahaman tentang risiko dalam rantai pasok, perlu dilakukan penilaian baik dalam kejadian risiko maupun sumber risiko. Penentuan bobot setiap risiko yang terjadi berdasarkan penilaian pakar berpengalaman mengenai rantai pasok cabai merah. Penilaian tersebut menghasilkan nilai ARP yang digunakan untuk menentukan prioritas risiko untuk melakukan aksi mitigasi risiko. Hasil perhitungan ARP sumber risiko pada tingkat petani, pengumpul, supplier dan indsutri kemudian menjadi risiko prioritas (Tabel 4). Berdasarkan nilai ARP dari hasil identifikasi risiko rantai pasok menunjukkan bahwa terdapat 9 prioritas risiko pada petani, 8 risiko pada pengumpul, 10 risiko pada supplier, dan 9 risiko pada industri yang dapat dimitigasi. Hal tersebut menandakan dari 9 prioritas risiko, risiko dengan nilai ARP tertinggi merupakan risiko yang paling mungkin dilakukan mitigasi.

HOR tahap 2 untuk identifikasi aksi-aksi untuk mencegah munculnya risiko (Preventive Actions (PAk)), melakukan mitigasi pada prioritas risiko berdasarkan nilai ARP. Penilaian tingkat kesulitan dan kemungkinan dari setiap mitigasi risiko (Difficulty (Dk)) dalam aksi mitigasi akan didapatkan nilai total efektivitas (ETD) yang tertinggi. Aksi mitigasi risiko pada petani paling mudah dilakukan dengan mendiskusikan dan menerapkan SOP yang disepakati bersama di Gapoktan (FPA2), sedangkan di pengumpul variasi dari kualitas produk perlu dilakukan standar dari produk yang akan diterima dan dipasarkan (CPA2). Aksi - aksi mitigasi dari masingmasing pelaku diuraikan pada Tabel 5 .

Tabel 4. Risiko prioritas aktor rantai pasok

\begin{tabular}{|c|c|c|}
\hline Kode & $\begin{array}{r}\text { Sumber Risiko } \\
\end{array}$ & ARP \\
\hline FA8 & SOP budidaya tidak dilakukan & 5.480 \\
\hline FA1 & Terjadinya kegagalan panen & 3.832 \\
\hline FA9 & Tidak ada pompa air saat musim kemarau & 3.600 \\
\hline FA6 & Ketidakpastian iklim dan cuaca & 3.090 \\
\hline FA10 & Ketidaksesuaian hasil produksi & 2.735 \\
\hline FA16 & Perubahan kualitas bahan baku (benih) & 2.443 \\
\hline FA3 & Kejenuhan dan penurunan produktivitas lahan & 2.359 \\
\hline FA11 & Peningkatan biaya produksi & 1.902 \\
\hline FA15 & Pendapatan petani menurun & 1.442 \\
\hline CA7 & SOP tidak dilaksanakan dengan baik & 3.068 \\
\hline CA5 & Hasil produksi tidak standar & 2.655 \\
\hline $\mathrm{CA} 2$ & Kurangnya suplai pasokan produk & 2.550 \\
\hline CA13 & Tidak berfungsinya Stasiun Agribisnis (STA) & 2.360 \\
\hline CA1 & Fluktuasi harga jual produk & 2.110 \\
\hline CA10 & Penundaan pembayaran hasil jual & 2.090 \\
\hline CA3 & Infrastruktur rusak & 2.074 \\
\hline CA9 & Terbatasnya sarana transportasi & 1.913 \\
\hline SA2 & Kurang/tidak adanya pasokan bahan baku & 5.880 \\
\hline SA14 & Penundaan waktu proses produksi & 5.513 \\
\hline SA10 & Kontrak kerja dengan UKM tertunda & 4.711 \\
\hline SA15 & Penambahan biaya produksi & 4.710 \\
\hline SA11 & Hasil produksi tidak sesuai spesifikasi & 3.974 \\
\hline SA8 & Tidak dapat memenuhi kebutuhan UKM & 3.723 \\
\hline SA5 & Kerusakan mesin/sarana proses produksi & 3.594 \\
\hline SA3 & Pemasok tdak memenuhi standar bahan baku & 3.141 \\
\hline SA16 & Kurangnya pasokan bahan pendukung & 3.057 \\
\hline SA1 & Fluktuasi harga beli bahan baku & 3.056 \\
\hline IA14 & Biaya produksi tinggi & 7.400 \\
\hline IA1 & Target produksi terlalu tinggi & 6.800 \\
\hline IA11 & Persaingan harga dengan produk lain & 5.954 \\
\hline IA3 & Kontrak kerja mitra distributor terhenti & 5.891 \\
\hline IA2 & Terjadinya pemberhentian produksi & 5.309 \\
\hline IA6 & Kurang pasokan bahan pendukung & 5.252 \\
\hline IA8 & Pesanan mendadak dari konsumen & 5.148 \\
\hline IA13 & Persyaratan dan biaya tinggi untuk pasar ekspor & 4122 \\
\hline IA9 & Penambahan biaya kemasan produk & 3300 \\
\hline
\end{tabular}


Tabel 5. Aksi mitigasi risiko

\begin{tabular}{llrr}
\multicolumn{1}{c}{ Mitigasi Risiko } & ETD & \multicolumn{1}{c}{ Dk } \\
\hline Kode & & 56734 & 3 \\
FPA2 & Membuat SOP bersama di Gapoktan & 39443 & 3 \\
FPA1 & SOP yang ada ditepati dan kontrol dengan ketat & 35747 & 4 \\
FPA8 & Gunakan PHT yang sesuai & 29123 & 4,5 \\
FPA4 & Gunakan teknologi prakiraan cuaca & 29109 & 3 \\
FPA3 & Menerapkan teknologi pengairan yang efisien & 27924 & 3 \\
FPA6 & Ketersediaan bibit di Toko Tani & 27577 & 5 \\
FPA5 & Lakukan seleksi/grading setelah panen & 16453 & 3 \\
FPA7 & Pola tanam sesuai permintaan pasar & 8317 & 3,5 \\
FPA9 & Pembelian produk dengan harga BEP oleh pemerintah & 22307 & 3 \\
CPA2 & Buat standarisasi produk & 19846 & 5 \\
CPA5 & Atur stabilisasi pasokan, atur pola panen & 14291 & 4,5 \\
CPA1 & Buat SOP dengan pengumpul lain & 13927 & 3,5 \\
CPA4 & Buat rumah kemasan bersama & 12183 & 4 \\
CPA8 & Ganti dengan yang kompatibel dan sesuai & 11337 & 3 \\
CPA6 & Bentuk koperasi, atur pembayaran ke petani & 9977 & 5 \\
CPA3 & Kerjasama atau buat sub unit usaha saprodi & 7910 & 4 \\
CPA7 & Pemerintah atur angkutan pangan/kereta api & 59569 & 3,5 \\
\hline SPA1 & Perbanyak mitra pemasok & 54345 & 3 \\
SPA5 & Cek proses produksi & 50608 & 3 \\
SPA10 & Perlu pemasok bahan baku cadangan & 49652 & 4,5 \\
SPA8 & Cari bahan baku yang lebih baik & 44509 & 3 \\
SPA6 & Atur produksi, luaskan tanaman & 40961 & 4 \\
SPA4 & Lakukan efisiensi dan cek kinerja & 40184 & 3 \\
SPA2 & Perlu gudang cadangan produk jadi & 39822 & 3,5 \\
SPA9 & Jalin hubungan atau kontrak & 31657 & 3,5 \\
SPA7 & Perlu mesin cadangan & 30845 & 3 \\
SPA3 & Perluas pasar lain & 61540 & 4 \\
\hline IPA5 & Memperluas pasar/permintaan produk & 59731 & 3 \\
IPA2 & Menyesuaikan dengan sumberdaya yang ada & 55769 & 3 \\
IPA1 & Mencari solusi pengurangan biaya & 49040 & 3,5 \\
IPA8 & Pengembangan pasar ekspor dengan online & 43682 & 3 \\
IPA6 & Mencari supplier lain & 42142 & 3 \\
IPA3 & Target konsumen/pasar yang berbeda & 39764 & 3,5 \\
IPA4 & Mencari distributor lain & 37659 & 4 \\
IPA7 & Menambah sumberdaya fisik dan TK & 15469 & 4 \\
IPA9 & Menaikkan harga produk akhir & & \\
\hline & & &
\end{tabular}

Tingkat keparahan terjadinya kejadian risiko di tingkat petani sebanyak 19 kejadian risiko dengan nilai keparahan menjadi 8 ialah perencanaan budidaya kurang sesuai, ketidaksesuaian kemasan panen, tanaman terserang hama penyakit. Sedangkan tingkat keparahan yang rendah dengan nilai keparahan 5, ialah ketidaksesuaian jumlah produksi di kebun dan pengumpul serta sulitnya akses terhadap pemodalan. Dapat dibenarkan bahwa petani mendapat akses permodalan yang cepat tetapi belum dapat dilihat hasil dari risiko yang harus dilakukan tersebut.

Kemudian, tingkat keparahan terjadinya kejadian risiko di tingkat pengumpul sebanyak 13 kejadian risiko dengan nilai keparahan menjadi 8,5 ialah kekurangan kuota pengiriman produk, ketidaksesuaian hasil produksi. Sedangkan tingkat keparahan yang rendah dengan nilai keparahan 6,5 ialah ketidaksesuaian penggunaan kemasan, harga produk rendah. Tingkat keparahan terjadinya kejadian risiko di tingkat supplier sebanyak 21 kejadian risiko dengan nilai keparahan menjadi 8,5 ialah bahan baku tidak memenuhi standar dan produksi tidak sesuai kriteria. Sedangkan tingkat keparahan yang rendah dengan nilai keparahan 6,5 ialah perubahan biaya produksi, pemasaran, dan sebagainya.

Tingkat keparahan terjadinya kejadian risiko di tingkat industri sebanyak 20 kejadian risiko dengan nilai keparahan menjadi 9 ialah kekurangan kapasitas produksi. Sedangkan tingkat keparahan yang rendah dengan nilai keparahan 7,5 ialah permintaan pasar tidak terpenuhi, kualitas produk menurun dan sebagian.

\section{Analisis Kelembagaan Rantai Pasok Cabai Merah}

Rantai pasok cabai merah di Kabupaten Garut terkait dengan pengelolaan suplai pasokan dan melibatkan aktor rantai dengan indikator kinerja dan risiko akan dilengkapi struktur kelembagaan melalui elemen-elemen kunci dalam pencapaian tujuan. Distribusi pasokan perlu adanya sebuah kebijakan 
dan implementasi secara terintegrasi. Penyusunan model kelembagaan rantai pasok cabai merah dilakukan dengan menganalisis elemen tujuan, kendala, lembaga yang terlibat, tolok ukur pencapaian tujuan dan perubahan yang dimungkinkan.

Elemen-elemen dan sub elemen meliputi: 1) elemen tujuan yang terdiri dari efisiensi rantai pasok, meningkatkan nilai tambah produk, mereprogram kegiatan-kegiatan antar pelaku, mendapatkan jaminan harga jual yang lebih baik, meningkatkan ketersediaan sarana, prasarana, GAP, GHP dan mendapatkan jaminan pasokan produk; 2) elemen kendala terdiri dari pola tanam yang tidak teratur, tingginya angka kehilangan hasil, fluktuasi harga jual, capacity building aktor yang belum memadai, ketidakseimbangan pasokan produk dan kuantitas hasil produksi tidak stabil; 3) elemen lembaga yang terdiri dari poktan/gapoktan/ koperasi, regulator dan fasilitator, collection center, lembaga permodalan, pasar induk terintegrasi, industri pengolahan, TTI/retail; 4) elemen tolok ukur terdiri dari mudahnya akses pasar, keterbukaan informasi dan koordinasi antar pelaku, terjaminnya jumlah pasokan, implementasi kegiatan sortasi dan pengemasan, terjaminnya harga produk untuk petani, penerapan GAP dan GHP, dan 5) elemen perubahan terdiri dari pengaturan pola tanam di sentra produksi, adanya harga minimum pembelian, ketersediaan sarana, prasarana yang memadai dan terjangkau, meningkatnya kapasitas SDM aktor, meningkatnya kualitas produk, adanya penerapan teknologi penanganan pascapanen, dan kejelasan informasi di aktor.

Masing-masing elemen dan sub elemen dianalisis menggunakan ISM dan berdasarkan informasi dari pendapat pakar. Hasil analisis ISM untuk elemen tujuan menunjukkan bahwa ketersediaan sarana, prasarana serta pemenuhan GAP, GHP yang digunakan dalam proses budidaya dan manajemen pengelolaan menjadi elemen kunci mendorong elemen lain sehingga mencapai tujuan akhir. Matriks DP-D elemen tujuan rantai pasok cabai merah terlihat pada Gambar 5. Pemenuhan dan ketersediaan sarana dapat mengefisiensi rantai pasok cabai merah dan mengintegrasi kegiatan yang direncakanan antar aktor. Hal tersebut menjadi daya ungkit selanjutnya dengan meningkatkan nilai tambah produk, jaminan harga jual produk dan jaminan pasokan produk cabai merah (Gambar 6).

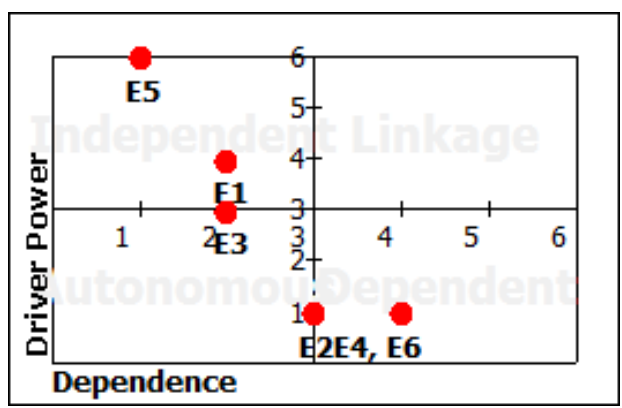

Gambar 6. Matriks DP-D elemen tujuan kelembagaan rantai pasok cabai merah

Hasil analisis ISM untuk elemen kendala menunjukkan bahwa capacity building untuk aktor rantai pasok menjadi elemen kunci dari kendala rantai pasok cabai merah. Pemenuhan kompetensi SDM sangat penting agar pola tanam yang tidak teratur dan tinginya angka kehilangan hasil dapat dikendalikan. Kendala utama tersebut menjadi kegiatan yang diperbaiki atau dievaluasi terlebih dahulu sebelum mendapatkan kuantitas hasil produksi yang stabil dan kesimbangan pasokan produk secara kontinu. Integrasi antar elemen kunci tersebut akan berpengaruh pada kuantitas dan pasokan produk agar tidak terjadi fluktuasi harga yang terlalu tajam (Gambar 7).

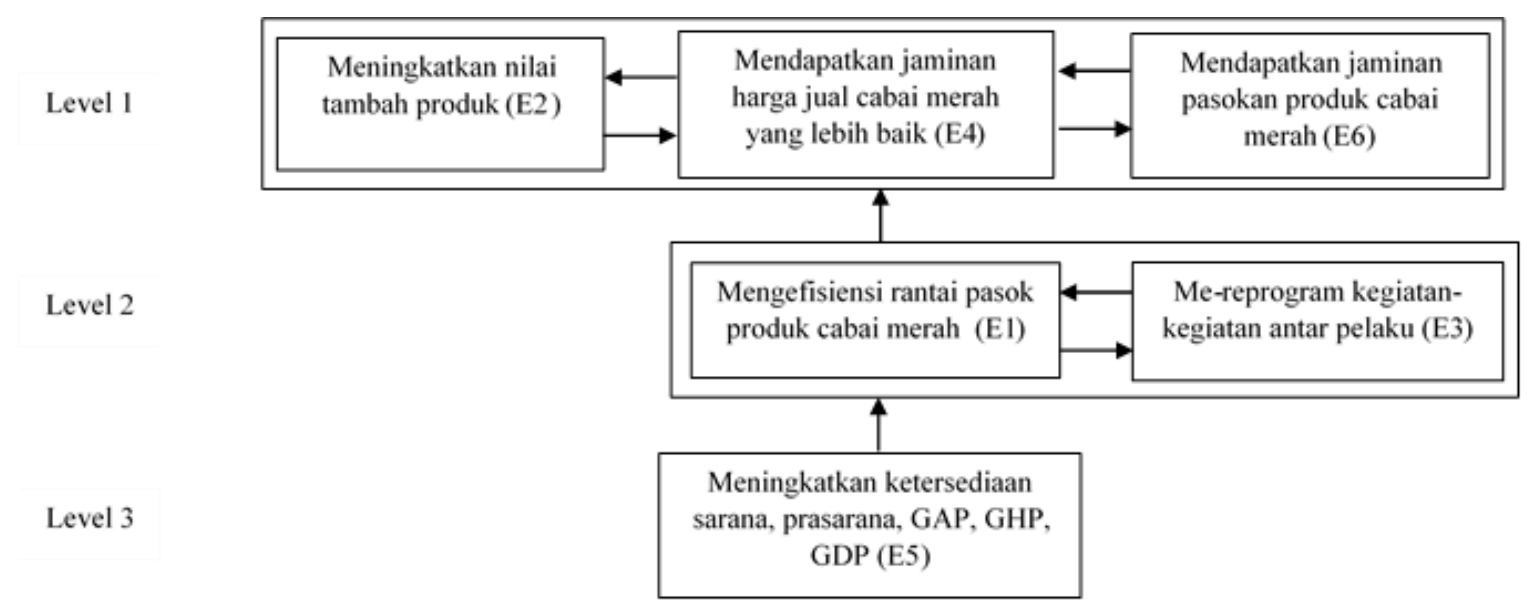

Gambar 5. Struktur hirarki antar sub elemen tujuan 
Level 1

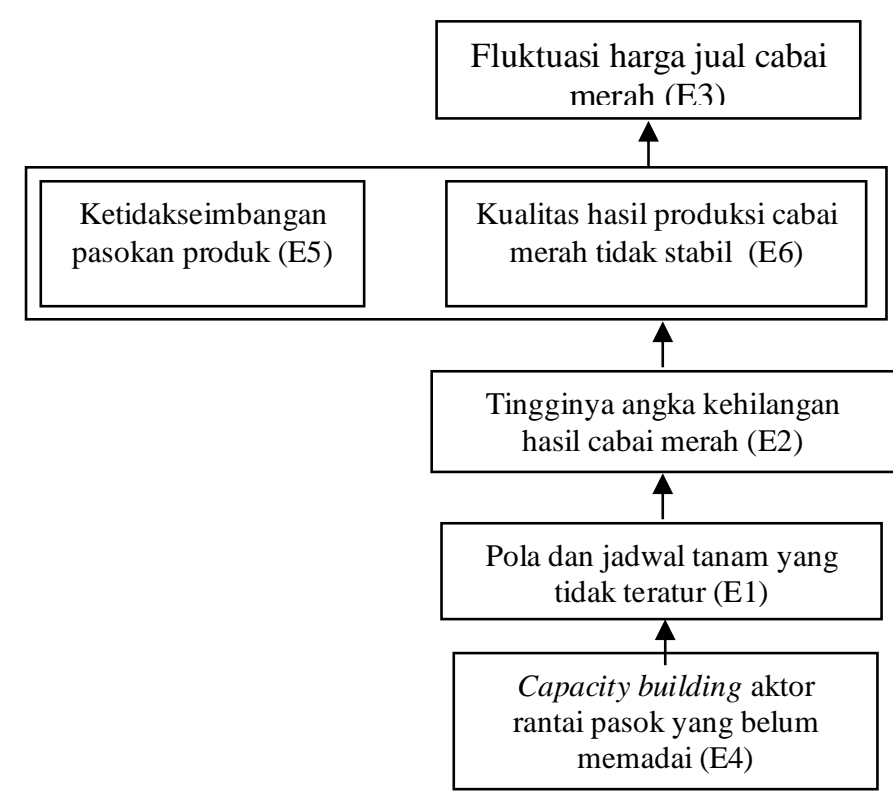

Gambar 7. Struktur hirarki antar sub elemen kendala

Selanjutnya, hasil analisis ISM untuk elemen tolok ukur tujuan model menunjukkan bahwa keterbukaan informasi dan koordinasi antar pelaku rantai pasok menjadi kunci utama dalam mencapai tolok ukur lain dengan membuka akses pasar, terjamin jumlah pasokan, adanya implementasi kegiatan sortasi dan pengemasan yang merupakan bagian dari teknologi penanganan pascapanen, serta penerapan GAP dan GHP yang baik. Tolok ukur dasar harus dapat dilakukan dan diupayakan terintegrasi agar dapat membuka tolok ukur lain dan menjamin harga beli produk untuk petani. Struktur kelembagaan rantai pasok cabai merah diawali dengan petani sebagai produsen hingga ke konsumen dapat dilihat pada Gambar 8.

Peningkatan strategi kinerja pada rantai pasok cabai merah berdasarkan pada kinerja dan risiko di Kabupaten Garut diharapkan para aktor rantai pasok meningkatkan koordinasi, integrasi antar pelaku dengan memanfaatkan keterbukaan informasi, pemenuhan sarana produksi, penerapan GAP yang tepat, memperbaiki mekanisme distribusi pasokan, sehingga dapat optimal untuk memenuhi permintaan konsumen, dan meningkatan daya saing pada industri cabai merah.

\section{Implikasi Manajerial}

Pada penelitian ini menunjukkan ada pengaruh positif dari manajemen rantai pasok terhadap kinerja. Peningkatan kinerja rantai pasok melalui aktor harus menjadi yang terbaik sehingga terjadi integrasi distribusi pasokan dengan keterbukaan informasi memanfaatkan teknologi informasi. Nilai kinerja terendah di petani sebesar $74,68 \%$ berpengaruh pada kejadian risiko yang diterima, sehingga pengaruh positif terhadap kinerja tidak stabil. Persaingan secara internal distribusi pasokan hanya menjadi unggulan internal, sehingga adanya peningkatan kinerja dan perbaikan struktur kelembagaan dalam rantai pasok persaingan distribusi pasokan dapat terjadi antar jaringan rantai pasok yang terbentuk.

\section{KESIMPULAN DAN SARAN}

\section{Kesimpulan}

Hasil analisis identifikasi pelaku rantai pasok cabai merah ialah struktur rantai pasok cabai merah umumnya terdiri dari petani/kelompok tani/ koperasi, pengepul, pedagang besar, pedagang eceran, supplier, industri kecil dan retail. Beberapa jalur distribusi produk telah terbentuk lama dan terdapat jalur distribusi yang tidak berfungsi serta proses bisnis yang bervariasi dalam satu daerah di Kabupaten Garut, Jawa Barat.

Hasil pembobotan AHP dengan mengadaptasi model evaluasi SCOR menghasilkan metrik pengukuran kinerja dengan bobot tertinggi ialah leadtime pemenuhan pesanan, fleksibilitas rantai pasok dan kesesuaian dengan standar mutu masing masing 0,151;0,130 dan 0,124. Kinerja rantai pasok cabai merah untuk dapat meminimalisasi waktu jeda tetap ditingkatkan. Didapatkan hasil kinerja pada pelaku rantai pasok cabai merah antara lain petani sebesar 74,6\%, pengumpul 76,8\%, supplier $82,5 \%$ dan IKM sebesar $81,9 \%$. Kinerja petani dan pedagang pengumpul harus ditingkatkan dan disejajarkan dengan kinerja supplier dan industri.

Pembinaan pada petani dan pengumpul diperlukan untuk meningkatkan kinerja dan dapat meminimalisasi risiko yang dihadapi oleh aktor rantai pasok. Berdasarkan perhitungan identifikasi risiko, dilakukan mitigasi risiko pada risiko dengan nilai ARP tertinggi. Terdapat 9 prioritas risiko petani, 8 prioritas risiko pengumpul, 10 prioritas risiko supplier dan 9 prioritas risiko industri yang akan dimitigasi risikonya. 


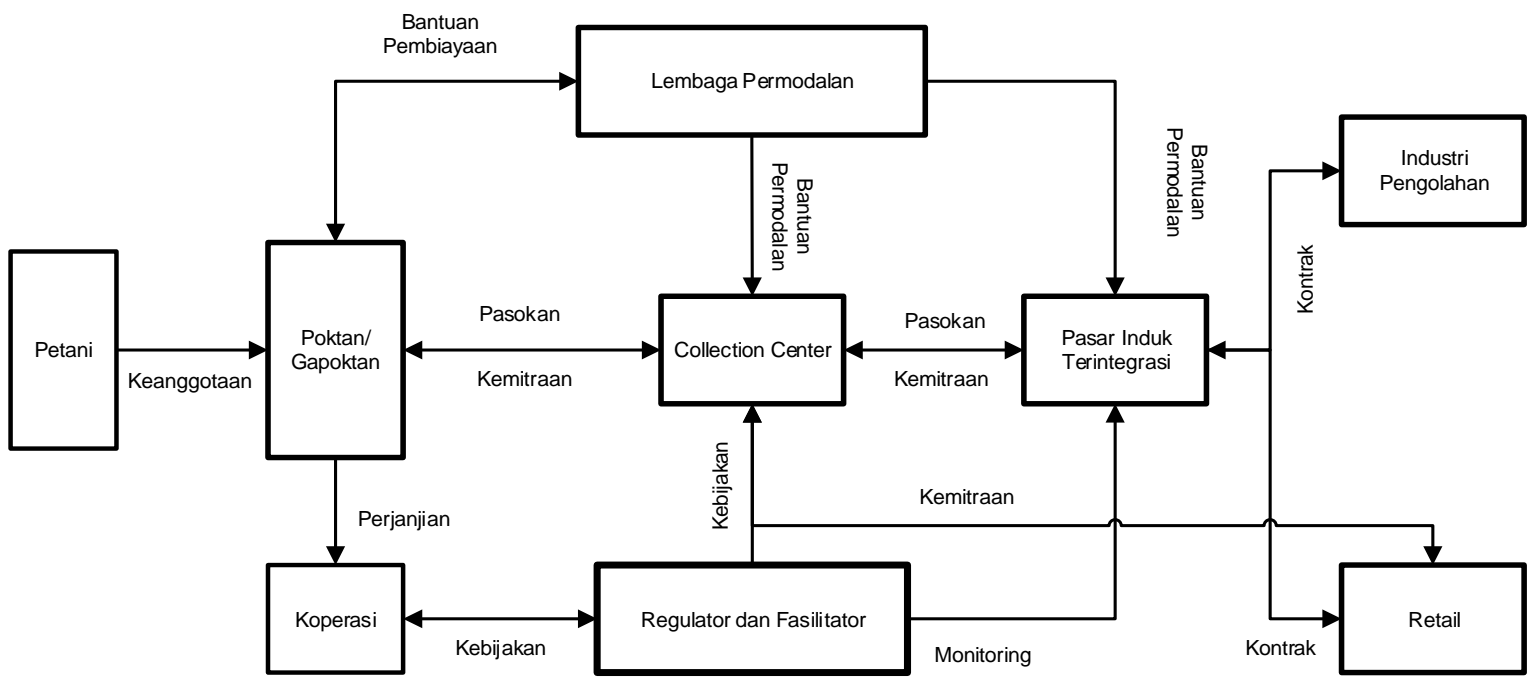

Keterangan :

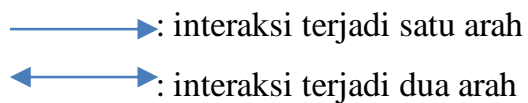

Gambar 8. Struktur kelembagaan rantai pasok cabai merah

Model kelembagaan rantai pasok cabai merah yang dijadikan dasar atau titik ungkit dalam pencapaian tujuan ialah menerapkan GAP, GHP secara tepat selaras dengan peningkatan kapasitas SDM dalam rantai distribusi cabai merah serta koordinasi dan keterbukaan informasi antar aktor/pelaku rantai pasok dapat ditingkatkan menjadi lebih baik. Upaya dalam rangka meningkatkan kinerja rantai pasok cabai merah di Kabupaten Garut diharapkan para pelaku di rantai pasok cabai merah meningkatkan koordinasi, integrasi antar pelaku dengan keterbukaan informasi, pemenuhan sarana produksi, penerapan GAP yang tepat, memperbaiki mekanisme distribusi pasokan, sehingga dapat optimal untuk memenuhi permintaan konsumen, dan meningkatan daya saing pada industri cabai merah.

\section{Saran}

Peningkatan kinerja aktor rantai pasok petani dan pengumpul dapat dilakukan dengan menerapkan GAP yang tepat, menjaga kualitas produk dan menstabilkan harga jual cabai merah dengan meratakan sentra produksi cabai merah. Mitigasi risiko dapat diminimumkan jika kinerja aktor dilaksanakan dengan optimal dalam rantai pasok cabai merah. Pengembangan model pembentukan harga beli produk dalam rantai pasok cabai merah, sehingga terjadi sistem manajemen rantai pasok yang berkeadilan.

\section{DAFTAR PUSTAKA}

Ahmad U. 2013. Teknologi Penanganan Pascapanen Buahan dan Sayuran. Yogyakarta : Graha Ilmu.
Arshinder KA and Desmukh SG. 2008. Supply chain coordination : perspectives, empirical studies and research directions . International Journal Production Economics. 115 (2) : 31 - 35.

[Distan] Anonim. 2010. Kabupaten Garut Dalam Angka. Dinas Pertanian Kabupaten Garut.

[BPS] Badan Pusat Statistik. 2017. Provinsi Jawa Barat dalam Angka 2016. Bandung : BPS.

Balfaqiha H, Zulkifli M, Nopiaha, Nizaroyani S, Malak T. Al-Noryb. 2016. Review of supply chain performance measurement systems: 1998- 2015. Computers in Industry. 82 :135150.

Bhagwat R dan Sharma MK. 2007. Performance measurement of Supply Chain Management: a balanced scorecard approach. Computers \& Industrial Engineering. 53: 43-62. doi: 0.1016/j.cie.2007.04.001.

Chopra S dan Meindl P. 2013. Supply Chain Management: Strategy, Planning, and Operation 5th Ed. London : Pearson Education Limited.

Clivillé V dan Berrah L. 2012. Overall performance measurement in a supply chain: towards a supplier-prime manufacturer based model. Journal Intell. Manuf. 23 (6) : 2459-2469.

Dinas Pertanian Jawa Barat. 2010. Perkembangan produksi tanaman pangan dan hortikultura Jawa Barat [Internet]. [diunduh 2017 Des 15]; Tersedia pada: http://www.jabar.go.id

Delipinar GE dan Batuhan K. 2016. Using SCOR model to gain competitive advantage: A Literature review. Procedia - Social and 
Behavioral Sciences. 229:398 - 406. DOI: 10.1016/j.sbspro.2016.07.150

Drzymalski J, Odrey NG, dan Wilson GR. 2010. Aggregating performance measures of a multiechelon supply chain using the analytical network and analytical hierarchy process. International Journal Services Econ. Manage. 2(3) : 286-306.

Eriyatno. 2013. Ilmu Sistem. Jilid 2. Meningkatkan Integrasi dan Koordinasi Manajemen. Bogor: Guna Widya.

Fearne A dan Hughes D. 2000. Success factors in the fresh produce supply chain: Insights from the UK. Supply Chain Management: An International Journal. 4(3):120-131.

Georgise FB, Klaus-Dieter T, dan Marcus S. 2013. Implementing the SCOR model best practices for supply chain improvement in developing countries. International Journal of $u$ - and $e$ Service, Science and Technology. 6 (4).

Giannakis dan Papadopoulos. 2016. Supply chain sustainability: A risk management approach. International Journal Production Economics. 171: 455-470.

Hidayat, S. Marimin, Suryani A, Sukardi, Yani M. 2012. Model identifikasi risiko dan strategi peningkatan nilai tambah pada rantai pasok kelapa sawit. Jurnal Teknik Industri. 14(2): 8996. ISSN : 1411-2485.

Jamehshooran BG, Awaluddin, Shaharoun M, Haron HN. 2015. Assesing supply chain performance through applying the SCOR model. International Journal Supply Chain. Management. 4 : (1).

Lambert DM. 2008. Supply Chain Management : Processes, Partnership and Performance. $3^{\text {rd }}$ edition. Florida : Supply Chain Management Institute.

Manuj I, Mentzer JT. 2008. Global supply chain risk management strategies. International Journal phys Distr Log. 38(3):192-223.

Marimin. 2004. Teknik dan Aplikasi Pengambilan Keputusan Kriteria Majemuk. Jakarta:Grasindo.

Marimin, Feifi D, Martini S, Astuti R, Suharjito, Hidayat S. 2010. Added value and performance analyses of edamame soybean supply chain: A case study. Operation and Supply Chain Management. 3(3):148-163. ISSN 1979. 3561|EISSN 1979-3871

Marimin dan Maghfiroh N. 2010. Aplikasi Teknik Pengambilan Keputusan dalam Manajemen Rantai pasok. Bogor (ID): IPB Press.

Monczka RM, Handfield RB, Giunipero LC, Patterson JL. 2009. Purchasing and Supply Chain Management. Boston (USA): Nelson Education Ltd.
Morgan W, Iwantoro S, dan Lestari AS. 2004. Improving Indonesian vegetable supply chains. Didalam: Johnson GI dan Hofman PJ, editor. Agri-product Supply Chain Management in Developing Countries. Proceeding of a Workshop; Bali, Indonesia. ACIAR. HIm 139141.

Oelviani R. 2013. Penerapan metode analytic hierarchy process untuk merumuskan strategi penguatan kinerja sistem agribisnis cabai merah di Kabupaten Temanggung. Informatika Pertanian. 22 (2): 11-19.

Pujawan IN. 2005. Supply Chain Management. Surabaya : Guna Widya.

Saaty Thomas L dan Niemera MP. 2006. A Framework for making a better decision: How to make more effective site selection, store closing, and other real estate decisions. Research Review. 13(1): 4. Tersedia di: http://mdm.gwu.edu/forman/

Saaty_Niemira_paper

Saptana. 2013. Manajemen rantai pasok (supply chain management) pada komoditas cabai merah besar di Jawa Tengah.

Septiani LR, Machfud, dan Yuliasih I. 2017. Peningkatan kinerja rantai pasok bawang merah (Studi Kasus: Kabupaten Brebes). Jurnal Teknologi Industri Pertanian. 27 (2):125- 140. DOI: 10.24961/j.tek.ind.pert.2017.27.2.125.

Setiawan A, Marimin, Arkeman Y, dan Udin F. 2011. Studi peningkatan kinerja manajemen rantai pasok sayuran dataran tinggi di Jawa Barat. Jurnal Agritech. 31 (1): 60-70.

[SCC] Supply-Chain Council. 2004. SCOR. Available: [http://www.supplychain.org/index.ww].

Van der Vorst. 2006. An overview : Performance Measurement in Agri-food Supply Chain Networks. Chapter 2 : 13- 24. Springer. Netherlands. Dalam: C., A J. Wijnands, R. Huirne, O. van Kooten (ed.). Quantifying the agri-food supply chain. Springer Science Business Media, Netherland.

Wang. 2003. Measuring transaction costs: an incomplete survey. Ronald Coase Institute, Chicago. Ronald Coase Institute Working Papers no. 2. http://coase.org/workingpapers/wp-2.pdf

Widyaningrum D dan Masruroh NA. 2012. Development of the sea fishery suppy chain performance measurement system : A Case Study. International Journal Supply Chain. Management. (1) : 3 .

Zhuang Y, Long C, Liping S, dan Jianxin C. 2012. Bioactive characteristic and antioxidant activities of nine pepper. Journal Functional Foods. 4 : 331-338. 